\title{
Municipal Solid Waste Heavy Fraction for Production of Turfgrass Sod
}

\author{
M.S. Flanagan, R.E. Schmidt, and R.B. Reneau, Jr. \\ Department of Crop and Soil Environmental Sciences, Virginia Polytechnic \\ Institute and State University, Blacksburg, VA 24061
}

Additional index words. Cynodon dactylon, Poa pratensis, garbage

\begin{abstract}
The "heavy fraction" portion of a municipal solid waste separation process was evaluated in field experiments as a soil amendment for producing turfgrass sod. Soil organic matter and concentrations of extractable $\mathrm{NO}_{3}-\mathrm{N}, \mathrm{P}, \mathrm{K}, \mathrm{Ca}$, and $\mathrm{Zn}$ in the soil increased with addition of heavy fraction. Soil incorporation of heavy fraction resulted in greater air, water, and total porosity and lower bulk density of a loamy sandy soil. .Sod strength measurements taken 8.5 and 9.5 months after seeding were higher for Kentucky bluegrass (Poaprutensis L.) grown in heavy-fraction-amended topsoil than for turf grown in topsoil only. The use of this by-product may reduce the time required to produce a marketable sod. Soil incorporation of heavy fraction did not influence post-transplant rooting of Kentucky bluegrass sod but enhanced rooting of bermudagrass [Cynodon dactylon (L.) Pers.] sod at the highest rate evaluated. Results of these studies suggest that the use of heavy fraction for sod production may provide cultural benefits in addition to reducing the volume of solid waste deposited in landfills.
\end{abstract}

Successfully producing turfgrass sod using sewage sludge as a rooting medium has been documented. Murray et al. (1980) reported that Kentucky bluegrass-red fescue (Festuca rubra L.) and tall fescue (F. arundinacea Schreb.)-Kentucky bluegrass mixtures sown in a 5- to $15-\mathrm{cm}$ layer of composted sewage sludge on the soil surface produced a harvestable sod within 9 months after seeding, compared with the 12 to 18 months usually required. Shortened production time also was documented by Neel et al. (1978), who produced harvestable sod of bahiagrass (Paspalum notatum Flügge) and bermudagrass [Cynodon dactylon (L.) Pers.] in 51 and 65 days, respectively, on rooting medium consisting of composted sewage sludge used alone or in combination with other waste materials. A sod production method described by Decker (1975), using sewage sludge on polyethylene plastic, reduced sod shipping weights by $30 \%$.

Americans generate $\approx 3.6 \times 10^{8} \mathrm{~kg} \cdot \mathrm{day}^{-1}$ of municipal solid waste, of which only $10 \%$ was recycled in 1987 (Budiansky and Black, 1987). If used as a soil amendment for sod production, the organic fraction of municipal refuse may provide some of the same benefits as sewage sludge and would reduce the volume of Solid waste deposited in landfills. The objectives of the experiments reported here were to evaluate the use of a municipal solid waste by-product as a soil amendment for turfgrass sod production by studying the effects on sod harvestability, post-transplant rooting of sod, soil fertility, and soil physical properties.

The material evaluated in these studies,

\footnotetext{
Received for publications 22 Feb. 1993. Accepted for publication 4 Mar. 1993. The cost of publishing this paper was defrayed in part by the payment of page charges. Under postal regulations, this paper therefore must be hereby marked advertisement solely to indicate this fact.
}

referred to as "heavy fraction" (HF), was a noncomposted by-product of an automated process separating municipal solid waste obtained from a facility in Baltimore County, $\mathrm{Md}$. In this process, metals ( $\mathrm{Al}$ and $\mathrm{Fe}$ ) and paper were removed mechanically and subsequently recycled. The remaining residue, or $\mathrm{HF}$, consisted mainly of food and yard waste, but also contained some paper and fragments of glass, metals, and plastics. Elemental analyses (total concentrations) performed before the experiments began indicated that the material contained (in $\mathrm{g} \cdot \mathrm{kg}^{-1}$ ) 11.2 total N, 2.0 P, 5.0 $\mathrm{K}, 14.6 \mathrm{Ca}$, and 2.6 Mg. Total $\mathrm{Mn}$ and $\mathrm{Zn}$ contents were 273 and $650 \mathrm{mg} \cdot \mathrm{kg}^{-1}$, respectively. Before the experiments, the HF was ground in a hammer mill to a $1.3-\mathrm{cm}$ particle size.

In May 1986, a field plot experiment was initiated on a Bojac loamy sand (coarse-loamy, mixed, thermic Typic Hapludult) on a landfill in Petersburg, Va. The HF was spread on $3 \mathrm{x}$ 6-m plots over the soil surface at thicknesses of $0,2.5,5.0$, and $10.0 \mathrm{~cm}$. The plots were separated by $1-\mathrm{m}$ alleyways, and treatments were arranged in a randomized complete block design replicated four times. Lime was applied to all plots at $4500 \mathrm{~kg} \cdot \mathrm{ha}^{-1}$, and the plots were then rototilled to $20 \mathrm{~cm}$ to ensure homogeneous mixing of soil and soil amendments. Control plots (plots receiving no $\mathrm{HF}$ ) were fertilized with a $10 \mathrm{~N}-17.2 \mathrm{P}-8.3 \mathrm{~K}$ granular fertilizer at $180 \mathrm{~kg} \cdot \mathrm{ha}^{-1}$. Plots and alleyways were subsequently sprigged to 'Vamont' bermudagrass at $27 \mathrm{~m}^{3} \cdot \mathrm{ha}^{-1}$ with a mechanical sprigging machine. No irrigation was applied at any time during the experiment, and plots were mowed only twice per growing season with a rotary mower at a cutting height of 4.0 $\mathrm{cm}$.

On 9 June 1988, $\approx 2$ years after turf establishment, soil samples were collected and sod was harvested to subsequently determine soil fertility, soil physical properties, and post- transplant sod rooting. The plots also were rated for turf density on this date using a scale of $0 \%$ to $100 \%$ turf cover in $5 \%$ increments. Five 1.9-cm-diameter soil cores were collected from the upper $10 \mathrm{~cm}$ of each plot, cornposited, and analyzed for organic matter content and Mehlich no. 1 extractable P, K, $\mathrm{Ca}, \mathrm{Mg}, \mathrm{Mn}$, and $\mathrm{Zn}$ by standard soil testing procedures (Donohue and Gettier, 1988). In addition, analyses for $\mathrm{NO}_{3}-\mathrm{N}$ and $\mathrm{NH}_{4}-\mathrm{N}$ were performed with an Orion Scientific (Boston) auto-analyzer following extraction with $2 \mathrm{M}$ KC1 (Brown, 1973; Keeney and Nelson, 1982). For measurements of soil physical properties, two $3.7-\mathrm{cm}$-diameter soil cores were collected from the surface $3.8 \mathrm{~cm}$ of each plot, and determinations of air, water, and total porosity were made on a Beckman (Fullerton, Calif.) model 930 air comparison pycnometer using procedures described by Schmidt (1980). Air and water porosity are defined as the proportion of the total soil volume occupied by air and water, respectively, following placement of a water-saturated core on a $60-\mathrm{cm}$ water $(5.81 \mathrm{kPa})$ tension table for $15 \mathrm{~h}$. Total porosity is the proportion of the total soil volume occupied by air after drying the core in a forced-air oven for $24 \mathrm{~h}$ at $75 \mathrm{C}$, and is the sum of air porosity and water porosity. Bulk density of each core was also determined by dividing the weight of the oven-dried core by its volume. Measurements of porosity and bulk density were averaged for the two cores collected per plot.

Two $30 \times 30-\mathrm{cm}$ sections of sod were harvested from each plot with a mechanical harvester set at a 1.9-cm cutting depth. The sod was immediately transported to the Virginia Tech Turfgrass Research Center (TRC) in Blacksburg, where it was transplanted the following day on $30 \times 30-\mathrm{cm}$ expanded metal frames that had been lightly worked into a newly prepared area of a Groseclose silt loam (clayey, mixed, mesic Typic Hapludult). The sod was irrigated immediately after transplanting and as needed for the duration of the experiment, and roots were allowed to grow for 3 weeks into the underlying soil through holes in the metal frames. On 1 July 1988 , post-transplant rooting measurements of sod were made using a variation of King's and Beard's method (1969), which was described by Schmidt et al. (1986). Post-transplant rooting measurements were averaged for the two sections of sod harvested and transplanted per plot.

A second field experiment was conducted at the TRC on the clayey subsoil of a disturbed Groseclose silt loam where topsoil had been removed to level the area. Individual plots were $0.6 \times 0.9 \mathrm{~m}$ and were separated by $0.6-\mathrm{m}$ alleyways. Treatments 'evaluated were three mixtures of topsoil from a stockpile of Groseclose silt loam and HF (containing 0\%. $50 \%$, and $75 \%$ HF by volume) and two depths of soil incorporation $(2.5$ and $5.0 \mathrm{~cm})$. The experiment was therefore a $2 \times 3$ factorial. and the six factorial treatment combinations were arranged in a randomized complete block design replicated four times.

The mixtures of topsoil and HF were pre- 
pared by combining the appropriate quantities of both components in an electrically powered cement mixer. Shallow beds were prepared for seeding by removing subsoil to 2.5 or $5.0 \mathrm{~cm}$ from designated plots with a square-end shovel and replacing the excavated soil with the appropriate mixture of topsoil and HF. Plots and alleyways were subsequently seeded to 'Plush' Kentucky bluegrass at $100 \mathrm{~kg} \cdot \mathrm{ha}^{-1}$ on 23 Sept. 1988. Irrigation was applied immediately after seeding and then as scheduled during subsequent weeks to ensure optimum germination. Plots amended with topsoil only ( $0 \% \mathrm{HF})$ were fertilized with a $10 \mathrm{~N}-4.3 \mathrm{P}-8.3 \mathrm{~K}$ granular fertilizer at $489 \mathrm{~kg} \cdot \mathrm{ha}^{-1}$ at seeding and subsequently on 27 Oct. and 26 Dec. 1988, and 2 May 1989. No fertilizer was applied to plots containing HF. The plots were mowed periodically to a height of $3.8 \mathrm{~cm}$ with a rotary mower, and clippings were removed. Irrigation was applied as needed during periods of moisture deficit. On 18 May 1989, plots were sprayed with a $50 \%$ wettable powder formulation of 1-(2-methylcyclohexyl)-3-phenylurea (siduron) at $9.8 \mathrm{~kg}$ a.i./ha for pre-emergent control of crabgrass (Digitaria spp.).

The plots were rated periodically between Mar. and July 1989 for color and density. Color scores were based on a scale of 1 to 9 , with $1=$ yellow and $9=$ dark green. Density was rated on a scale of $0 \%$ to $100 \%$ turf cover in $5 \%$ increments.

Sod strength measurements were made on 5 June and 13 July 1989 , which were $\approx 8.5$ and 9.5 months, respectively, after seeding. Sod was harvested from each plot with a mechanical sod harvester set at a 1.9-cm cutting depth. The measurements were subsequently made by removing two $30 \times 30-\mathrm{cm}$ sod pieces from each plot and stretching the sod with a portable apparatus modified after Rieke et al. (1968). Via this procedure, the lateral force required to break a strip of sod, which is an assay of root and rhizome development, was measured on a push/pull gauge. Force was recorded at the point of sod break and averaged for the two pieces of sod stretched per plot.

To measure post-transplant rooting, $30 \times$ $30-\mathrm{cm}$ pieces of sod (one from each plot) were harvested on 5 June 1989 and transplanted on $30 \times 30-\mathrm{cm}$ expanded metal frames that had been lightly worked into a newly prepared area of Groseclose silt loam. The sod was irrigated immediately after transplanting and as needed for the remainder of the experiment. Roots were allowed to grow for 4 weeks into the underlying soil through holes in the frames, and post-transplant rooting measurements were made on 3 July 1989 by the same methods described for the bermudagrass experiment. The entire procedure was repeated for sod harvested and transplanted on 13 July 1989; measurements were taken on 9 Aug. 1989.

Soil samples were collected from each plot on 25 Oct. 1989. Five 1.9-cm-diameter cores per plot were taken from the zone amended with the various mixtures of topsoil and $\mathrm{HF}$. composited, and analyzed for extractable $\mathrm{NO}_{3}$ $\mathrm{N}, \mathrm{NH}_{4}-\mathrm{N}, \mathrm{P}, \mathrm{K}, \mathrm{Ca}, \mathrm{Mg}, \mathrm{Mn}$, and $\mathrm{Zn}$ by the methods described for the bermudagrass experiment.
Data were analyzed statistically using SAS computer programs (SAS Institute, 1985). Analyses of variance were performed to test for treatment effects. Contrasts were used for all variables to compare means from each $\mathrm{HF}$ treatment to the controls.

Soil fertility was improved in both studies by adding HF. Concentrations of extractable $\mathrm{NO}_{3}-\mathrm{N}, \mathrm{P}, \mathrm{K}, \mathrm{Ca}$, and $\mathrm{Zn}$ were increased by $\mathrm{HF}$ in the experiment with bermudagrass (Table 1 ), as were concentrations of $\mathrm{P}, \mathrm{Ca}$, and $\mathrm{Zn}$ in the experiment with Kentucky bluegrass (Table 2). Since no fertilizer was applied to HFamended plots in either study, these data imply that fertilizer needs (and hence costs) may be reduced if this by-product were used as a soil amendment in an actual sod production operation.

Incorporating $\mathrm{HF}$ altered the physical properties of Bojac loamy sand planted to bermudagrass (Table 3). Increases in air and water porosity indicate that aeration and water-holding capacity of the Bojac loamy sand were enhanced by adding HF. The soil's bulk density was reduced $19.5 \%$ relative to the control by incorporating $10 \mathrm{~cm}$ of HF. These findings imply that the use of this by-product by commercial sod growers may result in the production of a lighter sod that would be easier to handle and transplant and less costly to ship. Greater porosity and lower bulk density were likely influenced by soil organic matter content, which increased linearly with amount of applied HF (Table 1).

Sod strength of Kentucky bluegrass increased linearly with amount of HF for both sod harvest dates (Table 4). Sod strength was greater for turf grown in $5.0 \mathrm{~cm}$ of mixtures on 5 June but was not affected by depth on 13 July. Differences in sod strength for the 5 June measurements are particularly noteworthy in that they indicate differences in sod harvestability. Previous experience with this method of measuring sod strength has shown that a harvestable sod has a strength $\geq 20 \mathrm{~kg}$ (Taylor and Schmidt, 1980). Strength of Kentucky bluegrass sod grown in $75 \% \mathrm{HF}$ at 2.5 and 5.0 $\mathrm{cm}$ and $50 \% \mathrm{HF}$ at $5.0 \mathrm{~cm}$ exceeded $20 \mathrm{~kg}$, whereas that grown in top soil only did not. Thus, HF soil amendments produced a

Table 1. Concentration of extractable elements (in mg. $\mathrm{kg}^{-1}$ ) and organic matter content in the surface 10.0 $\mathrm{cm}$ of a loamy sandy soil amended with various amounts of heavy fraction (HF) and planted to bermudagrass.

\begin{tabular}{|c|c|c|c|c|c|c|c|c|c|}
\hline $\begin{array}{l}\text { HF layer } \\
\text { thickness } \\
\text { (cm) }\end{array}$ & $\mathrm{NO}_{3}-\mathrm{N}$ & $\mathrm{NH}_{4}-\mathrm{N}$ & $\mathrm{P}$ & $\mathbf{K}$ & $\mathrm{Ca}$ & $\mathrm{Mg}$ & $\mathrm{Mn}$ & $\mathrm{Zn}$ & $\begin{array}{c}\text { Organic } \\
\text { matter } \\
\left(\mathrm{g}^{\prime} \mathrm{kg}^{-\mathbf{l}}\right)\end{array}$ \\
\hline$\overline{0^{z}}$ & 0.3 & 1.1 & 20 & 43 & 561 & 167 & 26 & 1.6 & 12 \\
\hline 2.5 & $1.7^{\mathrm{Ns}}$ & $3.2^{\mathrm{Ns}}$ & $27^{\mathrm{Ns}}$ & $55^{\mathrm{Ns}}$ & $777^{\mathrm{Ns}}$ & $118^{* *}$ & $30^{\mathrm{Ns}}$ & $11^{\mathrm{Ns}}$ & $18^{*}$ \\
\hline 5.0 & $1.6^{\mathrm{Ns}}$ & $2.4^{\mathrm{Ns}}$ & $28^{\mathrm{Ns}}$ & $56^{\mathrm{NS}}$ & $864^{\mathrm{Ns}}$ & $131^{*}$ & $30^{\mathrm{Ns}}$ & $14^{*}$ & $21^{* *}$ \\
\hline 10.0 & $5.5^{* * *}$ & $2.0^{\mathrm{ss}}$ & $57^{* *}$ & $104^{* *}$ & $1758^{* *}$ & $130^{*}$ & $44^{\mathrm{Ns}}$ & $29^{* *}$ & $27^{* *}$ \\
\hline
\end{tabular}

${ }^{\mathrm{z}}$ Control; fertilized, no HF.

Ns, *. ${ }^{* *}$ Nonsignificant or significant at $P \leq 0.05$ or 0.01 , respectively. Differs from control by orthogonal contrasts.

Table 2. Concentration of extractable elements (in $\mathrm{mg} \cdot \mathrm{kg}^{-1}$ ) in topsoil mixtures consisting of various heavy fraction (HF) amounts and depths of incorporation (Kentucky bluegrass experiment).

\begin{tabular}{lccccccccc}
\hline $\begin{array}{l}\mathrm{HF} \\
\text { applied } \\
(\%)^{2}\end{array}$ & $\begin{array}{c}\text { Depth } \\
(\mathrm{cm})\end{array}$ & $\mathrm{NO}_{3}-\mathrm{N}$ & $\mathrm{NH}_{4}-\mathrm{N}$ & $\mathrm{P}$ & $\mathrm{K}$ & $\mathrm{Ca}$ & $\mathbf{M g}$ & $\mathrm{Mn}$ & $\mathrm{Zn}$ \\
\hline $0^{y}$ & 2.5 & 5.9 & 8.4 & 23 & 109 & 428 & 87 & 32 & 2.3 \\
$0^{y}$ & 5.0 & 3.5 & 11 & 22 & 111 & 427 & 87 & 36 & 2.3 \\
50 & 2.5 & $2.0^{\text {Ns }}$ & $19^{\text {Ns }}$ & $48^{* *}$ & $136^{\text {Ns }}$ & $851^{*}$ & $107^{\text {Ns }}$ & $46^{*}$ & $15^{\text {Ns }}$ \\
50 & 5.0 & $5.8^{\text {Ns }}$ & $24^{\text {ss }}$ & $36^{* *}$ & $98^{\text {Ns }}$ & $944^{*}$ & $9^{\text {Ns }}$ & $37^{\text {Ns }}$ & $19^{* *}$ \\
75 & 2.5 & $2.9^{\text {Ns }}$ & $19^{\text {Ns }}$ & $38^{* *}$ & $95^{\text {Ns }}$ & $806^{* *}$ & $92^{\text {Ns }}$ & $23^{\text {Ns }}$ & $21^{* *}$ \\
75 & 5.0 & $7.0^{\text {Ns }}$ & $30^{\text {Ns }}$ & $5^{* *}$ & $80^{*}$ & $1277^{\text {*** }}$ & $94^{\text {Ns }}$ & $29^{\text {Ns }}$ & $32^{* *}$ \\
\hline
\end{tabular}

${ }^{\mathrm{z}}$ Amount by volume.

Control; fertilized, no HF.

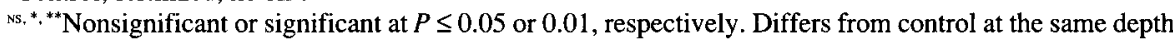
by orthogonal contrasts.

Table 3. Physical properties of a loamy sandy soil, turf density of bermudagrass, and post-transplant rooting, based on vertical uplift, of bermudagrass sod as influenced by soil incorporation of various depths of heavy fraction (HF).

\begin{tabular}{|c|c|c|c|c|c|c|}
\hline \multirow{2}{*}{$\begin{array}{l}\text { HF layer } \\
\text { depth } \\
(\mathrm{cm})\end{array}$} & \multicolumn{3}{|c|}{ Porosity } & \multicolumn{2}{|c|}{ Density } & \multirow{2}{*}{$\begin{array}{c}\text { Vertical } \\
\text { lift } \\
(\mathbf{k g})^{\mathrm{y}}\end{array}$} \\
\hline & $\begin{array}{l}\text { Air } \\
(\%)\end{array}$ & $\begin{array}{c}\text { Water } \\
(\%)\end{array}$ & $\begin{array}{c}\text { Total } \\
(\%)\end{array}$ & $\begin{array}{c}\text { Bulk } \\
\left(\mathrm{g} \cdot \mathrm{cm}^{-3}\right)\end{array}$ & $\begin{array}{c}\text { Turf }^{2} \\
(\%)\end{array}$ & \\
\hline $0^{x}$ & 7.5 & 21.1 & 28.6 & 1.69 & 12.5 & 53.0 \\
\hline 2.5 & $10.3^{\text {Ns }}$ & $23.5^{\text {Ns }}$ & $33.9^{* *}$ & $1.50^{* *}$ & $75.0^{* *}$ & $49.4^{\mathrm{Ns}}$ \\
\hline 5.0 & $9.6^{\mathrm{NS}}$ & $23.2^{\mathrm{NS}}$ & $32.8^{*}$ & $1.52^{* *}$ & $85.0^{* *}$ & $49.0^{\mathrm{ss}}$ \\
\hline 10.0 & $11.8^{\mathrm{Ns}}$ & $24.8^{*}$ & $36.6^{* *}$ & $1.36^{* *}$ & $81.3^{* *}$ & $75.3^{*}$ \\
\hline
\end{tabular}

Plots were rated for turf density on 9 June 1988 using a scale of $0 \%$ (no turf) to $100 \%$ in $5 \%$ increments. 'Verticall lifi batsed on a 900 -c $\mathrm{cm}^{2}$ surface area.

Control; tertilized, no HF.

s. Nonsignificant or significant at $P \leq 0.05$ or 0.01 , respectively. Differs from control by orthogonal contrasts. 
Table 4. Color, density, sod strength, and post-transplant rooting, based on vertical lift, of Kentucky bluegrass sod grown on rooting media consisting of various heavy fraction (HF) amounts and depths of incorporation, 1989.

\begin{tabular}{|c|c|c|c|c|c|c|c|}
\hline \multirow{3}{*}{$\begin{array}{l}\mathrm{HF} \\
\text { applied } \\
(\%)^{\mathrm{x}}\end{array}$} & \multirow{3}{*}{$\begin{array}{c}\text { HF layer } \\
\text { depth } \\
(\mathrm{cm})\end{array}$} & \multicolumn{2}{|c|}{ Turf } & \multirow{2}{*}{\multicolumn{2}{|c|}{ Sod strength $(\mathrm{kg})^{\mathrm{y}}$}} & \multirow{2}{*}{\multicolumn{2}{|c|}{ Vertical lift $(\mathrm{kg})^{\mathrm{y}}$}} \\
\hline & & \multirow[b]{2}{*}{ Color ${ }^{\mathrm{w}}$} & \multirow{2}{*}{$\begin{array}{c}\text { Density }^{2} \\
(\%)\end{array}$} & & & & \\
\hline & & & & 5 Jüne & 13 July & 3 July & 9 Aug. \\
\hline$\overline{0^{v}}$ & 2.5 & 7.2 & 78.3 & 11.5 & 23.0 & 36.8 & 33.0 \\
\hline $0^{v}$ & 5.0 & 7.3 & 82.5 & 13.5 & 18.1 & 42.3 & 39.8 \\
\hline 50 & 2.5 & $6.8^{\mathrm{NS}}$ & $90.8^{*}$ & $18.5^{*}$ & $24.0^{\mathrm{NS}}$ & $37.0^{\mathrm{Ns}}$ & $40.3^{\mathrm{Ns}}$ \\
\hline 50 & 5.0 & $7.1^{\mathrm{NS}}$ & $91.5^{\mathrm{Ns}}$ & $23.9^{* *}$ & $29.1^{*}$ & $43.3^{\mathrm{NS}}$ & $31.5^{\mathrm{Ns}}$ \\
\hline 75 & 2.5 & $6.9^{\mathrm{Ns}}$ & $93.3^{* *}$ & $23.0^{* *}$ & $36.6^{* *}$ & $41.5^{\mathrm{NS}}$ & $46.8^{*}$ \\
\hline 75 & 5.0 & $7.5^{\mathrm{Ns}}$ & $98.1^{* *}$ & $30.1^{* *}$ & $32.9^{* *}$ & $36.8^{\text {NS }}$ & $37.3^{\mathrm{Ns}}$ \\
\hline
\end{tabular}

${ }^{2}$ Plots were rated for turf density on a scale of $0 \%$ to $100 \%$ turf cover in $5 \%$ increments. Density estimates were averaged for multiple ratings.

${ }^{y}$ Sod strength based on a $30-\mathrm{cm}$ edge that was ruptured; vertical lift based on a $900-\mathrm{cm}^{2}$ surface area.

Amount by volume.

"Plots were rated for color on a scale of 1 to 9 , with $1=$ yellow and $9=$ dark green. Color scores were averaged for multiple ratings.

"Control; fertilized, no HF.

Ns, ${ }^{*}$ ** Nonsignificant or significant at $P \leq 0.05$ or 0.01 , respectively. Differs from control at the same $\mathrm{HF}$ thickness by orthogonal contrasts.

harvestable sod in 8.5 months, while sod grown in topsoil containing no HF did not. These data indicate that the time required to produce Kentucky bluegrass sod may be reduced if $\mathrm{HF}$ were used as a soil amendment by commercial sod producers. Although soil physical properties were not measured in the bluegrass experiment, it is likely that mixtures containing HF provided looser, better aerated media that were more favorable for growth of roots and rhizomes than topsoil not blended with HF.

Measured by resistance to vertical lift, rooting of transplanted Kentucky bluegrass sod grown in topsoil containing HF usually did not differ from that of sod grown in topsoil only (Table 4). It is important to emphasize, however, that root growth was not inhibited by HF. Burns and Boswell (1976) reported detrimental effects of sewage sludge on rooting of centipedegrass [Eremochloa ophiuroides (Munro.) Hack.]. Post-transplant rooting (measured by resistance to lift) of bermudagrass sod grown in soil amended with $10.0 \mathrm{~cm}$ of HF was significantly greater than that of sod harvested from other plots (Table 3). Rainfall was sparse and soil was dry before harvesting the bermudagrass sod, and the hard soil made cutting the sod difficult. There was a noticeable difference, however, in ease of harvest for sod grown in the plots amended with $10.0 \mathrm{~cm}$ of HF. Enhanced rooting and easier harvesting were probably influenced by greater moisture retention from adding HF to the soil. As noted, water porosity, which is an estimate of soil micropore space and, hence, an indication of a soil's capacity to retain water, increased with increasing amount of applied HF (Table 3). Rooting of sod after transplanting is influ-

enced by soil moisture content at harvest (Beard, 1973).

Deal and Engel (1965) found that applications of $\mathrm{Zn}$ at $28 \mathrm{~kg} \cdot \mathrm{ha}^{-1}$ strongly inhibited rhizome growth in 'Merion' Kentucky bluegrass. Although soil concentrations of extractable $\mathrm{Zn}$ increased linearly with amount of applied HF (Tables 1 and 2), no phytotoxicity was observed in the experiments reported here. In fact, density of bermudagrass and bluegrass was greater for HF-grown turf than for turf grown in soil only (Tables 3 and 4). Turf coverage for bermudagrass was very poor in control plots (Table 3), which probably reflects the lower fertility and water porosity measured in these plots. The HF-amended soil, however, supported bermudagrass growth under nonfertilized, nonirrigated conditions for 2 years. When averaged over the entire experiment, color of Kentucky bluegrass for HF-grown turf did not differ from turf grown in topsoil only (Table 4). These findings emphasize the fertility value of $\mathrm{HF}$ as a soil amendment, since only topsoil plots received periodic fertilizer applications.

Results of these experiments indicate that the use of municipal solid waste HF as a soil amendment for turfgrass sod production may be a viable recycling option. Potential benefits include 1) improved soil fertility, 2) greater soil aeration and moisture retention, 3) lower shipping costs due to production of sod on a soil of lower bulk density, 4) replacement of soil organic matter depleted by sod harvesting, and 5) shorter time required to produce a mature marketable sod. Despite the apparent cultural benefits of this material, the environmental effects of HF also must be assessed before this by-product may be used in actual sod production operations.

\section{Literature Cited}

Beard, J.B. 1973. Turfgrass: Science and culture. Prentice Hall, Englewood Cliffs, N.J.

Brown, M.W. 1973. A highly sensitive automated technique for the determination of ammonium nitrogen. J. Sci. Food Agr. 24:1119-1 123.

Budiansky, S. and R.F. Black. 1987. Tons and tons of trash and no place to put it. U.S. News World Rpt. 103(24):58-62.

Bums, R.E. and F.C. Boswell. 1976. Effect of municipal sewage sludge on rooting of grass cuttings. Agron. J. 68:382-384.

Deal, E.E. and R.E. Engel. 1965. Iron, manganese, boron, and zinc: Effects on growth of Merion Kentucky bluegrass. Agron. J. 57:553-555.

Decker, H.F. 1975. Sewage sod system saves time. Weeds, Trees, Turf 14(6):40-41.

Donohue, S.J. and S.W. Gettier. 1988. Soil testing and plant analysis laboratory procedures. Virginia Coop. Ext. Serv. Publ. 452-881.
Keeney, D.R. and D.W. Nelson. 1982. NitrogenInorganic forms, p. 643698. In: A.L. Page, R.H. Miller, and D.R. Keeney (eds.). Methods of soil analysis, part 2: Chemical and microbiological properties. 2nd ed. Amer. Soc. Agron., Soil Sci. Soc. Amer., Madison, Wis.

King, J.W. and J.B. Beard. 1969. Measuringrooting of sodded turfs. Agron. J. 61:497-498.

Murray, J.J., J.C. Patterson, and D.J. Wehner. 1980 Use of sewage sludge compost in turfgrass production, p. 66-70. In: Proc. Natl. Conf. Ind. Municipal Sludge Utilization Disposal, Washington, D.C., 28-30 May 1980. Information Transfer, Silver Spring, Md.

Neel, P.L., E.O. Burt, P. Busey, and G.H. Snyder. 1978. Sod production in shallow beds of waste materials. J. Amer. Soc. Hort. Sci. 103:549-553.

Rieke, P.E., J.B. Beard, and C.M. Hansen. 1968. A technique to measure sod strength for use in sod production studies. Agron. Abstr. p. 60.

SAS Institute. 1985. SAS user's guide: Statistics. version 5 ed. SAS Institute, Cary, N.C.

Schmidt, R.E. 1980. Bentgrass growth in relation to soil properties of Typic Hapludalfs soil variously modified for a golf green, p. 205-214. In: J.B. Beard (ed.). Proc. 3rd Intl. Turfgrass Res. Conf., Munich, West Germany, 11-13 July 1977. Amer. Soc. Agron., Crop Sci. Soc. Amer., Soil Sci. Soc. Amer., Intl. Turfgrass Soc., Madison, Wis.

Schmidt, R.E., R.H. White, and S.W. Bingham. 1986. Technique to measure rooting of sods grown in small containers. Agron. J. 78:212216.

Taylor, L.H. and R.E. Schmidt. 1980. Differences in sod strength, rooting, and turfgrass quality of Kentucky bluegrass cultivars resulting from seasonal conditions. In: J.B. Beard (ed.). Proc. 3rd Intl. Turfgrass Res. Conf., Munich, West Germany, 11-13 July 1977. Amer. Soc. Agron., Crop Sci. Soc. Amer., Soil Sci. Soc. Amer., Intl. Turfgrass Soc., Madison, Wis. 